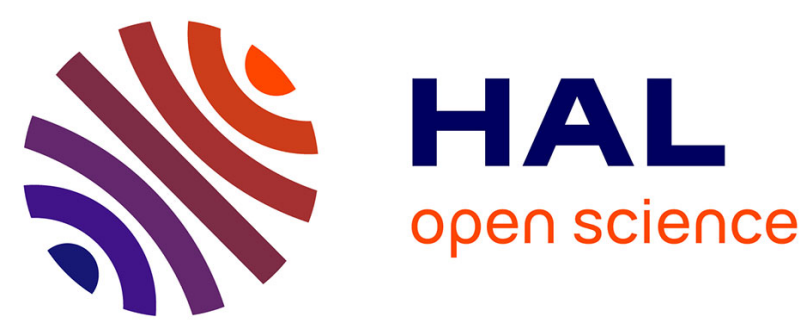

\title{
Glutamate and $\mathrm{CO} 2$ production from glutamine in incubated enterocytes of adult and very old rats
}

Dominique Meynial-Denis, Guy Bielicki, Anne-Marie Beaufrère, Michelle

Mignon, Philippe Patureau Mirand, Jean-Pierre Renou

\section{To cite this version:}

Dominique Meynial-Denis, Guy Bielicki, Anne-Marie Beaufrère, Michelle Mignon, Philippe Patureau Mirand, et al.. Glutamate and $\mathrm{CO} 2$ production from glutamine in incubated enterocytes of adult and very old rats. Journal of Nutritional Biochemistry, 2013, 24 (4), pp.688-692. 10.1016/j.jnutbio.2012.03.019 . hal-02651144

HAL Id: hal-02651144

https: / hal.inrae.fr/hal-02651144

Submitted on 29 May 2020

HAL is a multi-disciplinary open access archive for the deposit and dissemination of scientific research documents, whether they are published or not. The documents may come from teaching and research institutions in France or abroad, or from public or private research centers.
L'archive ouverte pluridisciplinaire HAL, est destinée au dépôt et à la diffusion de documents scientifiques de niveau recherche, publiés ou non, émanant des établissements d'enseignement et de recherche français ou étrangers, des laboratoires publics ou privés. 
Glutamate and $\mathrm{CO}_{2}$ production from glutamine in incubated enterocytes

\section{of adult and very old rats}

Dominique Meynial-Denis ${ }^{1}$, Guy Bielicki ${ }^{2}$, Anne-Marie Beaufrère ${ }^{3}$, Michelle Mignon ${ }^{1}$, Jean-Pierre Renou ${ }^{2}$ and Philippe Patureau Mirand ${ }^{1}$

From the ${ }^{1}$ INRA, UMR 1019, UNH, CRNH Auvergne, 63009 CLERMONT-FERRAND, France; ${ }^{2}$ INRA, Plateforme de Résonance Magnétique des Systèmes Biologiques, QuaPA Unit, Saint Genes Champanelle, F-63122, France; ${ }^{3}$ CHU Clermont-Ferrand, Service d'Anatomie Pathologique, Hôpital Estaing, 63003 CLERMONT-FERRAND Cedex1, France.

\section{Short Title:}

Correspondence: Dominique Meynial-Denis, PhD, Human Nutrition Unit, INRA and Human Nutrition Research Center, Theix 63122 - St Genes Champanelle, France.

Electronic mail may be sent to dominique.meynial@clermont.inra.fr (Dominique MeynialDenis) 
ABSTRACT.

Background: Glutamine is the major fuel for enterocytes and promotes growth of intestinal mucosa. Although oral glutamine exerts a positive effect on intestinal villus height in very old rats, how glutamine was used by enterocytes is unclear.

Methods: Adult (8-mo) and very old (27-mo) female rats were exposed to glutamine supplementation during $50 \%$ of their age. Treated rats received glutamine added to the drink and control rats only water. Jejunal epithelial cells $\left(\sim 300 \times 10^{6}\right.$ cells) were incubated in oxygenated Krebs-Henseleit buffer for 30 min containing $\left[1-{ }^{13} \mathrm{C}\right]$ glutamine $(\sim 17 \mathrm{M})$ for analysis of glutamine metabolites by ${ }^{13} \mathrm{C}$ NMR. An aliquot fraction was incubated in the presence of $\left[\mathrm{U}^{-14} \mathrm{C}\right]$ glutamine for measuring produced $\mathrm{CO}_{2}$. $98 \%$ of cells remained viable after 30 min of incubation. Biochemical reactions were stopped by addition of perchloric acid.

Results: Glutamine pretreatment increased glutamate production in very old rats (from NMR data). By contrast, this treatment decreased $\mathrm{CO}_{2}$ production in very old animals. Possibly glutamate could be metabolized in the mucosa in first pass or in $\mathrm{CO}_{2}$. The importance of each pathway was dependent of both age and glutamine pretreatment. The ratio $\mathrm{CO}_{2}$ /Glutamate, very high in control very old rats, became similar at both ages after glutamine pretreatment, as if very old enterocytes recovered metabolic capacities of adult enterocytes.

Conclusion: Our results suggest that, long-term treatment with glutamine started before advanced age: 1) it prevented the loss of rat body weight without limiting sarcopenia, 2) had a beneficial effect on enterocytes from very old rats by probably favoring the role of 
glutamate as precursor for glutathione, arginine, and proline biosynthesis, not detected in ${ }^{13} \mathrm{C}$ NMR spectra in our experimental conditions. Further investigations would be warranted to explore these metabolic pathways.

Keywords:

${ }^{13} \mathrm{C}$ NMR, glutamine supplementation, histomorphometry, radiometry, jejunum 
Aging, an inevitable biological process, leads, in particular, to a progressive loss of muscle mass associated with a decline in strength or sarcopenia in humans and rodents (Young, 1990; Evans 1995; Dutta \& Hadley, 1995; numerous inflammatory episodes (Yoshikawa, 1984; Papet, Dardevet, et al., 2003) that induce both a state of chronic, continuous stress (as reported by Mayer et al., 2001 in general process of stress) and a general decline in the physiological function leading to morbidity and mortality. There is generally a decrease of function of the gastrointestinal tract, but there may be loss of adaptability in response to changes in diet or nutritional stress (Drozdowski and Thomson, 2006). Pathological alterations which might lead to minor overall intestinal functional variations in the youth because of a process of adaptation, may lead to much more serious events in the elderly.

The reduced mass of muscle, in the elderly may limit the availability of glutamine (muscle being important glutamine producer in the whole body), which is essential for immune cell function (Munro, 1982; Young, 1990; Mondello et al., 2010) and intestine oxidative fuel (Curi et al., 2005) in animals and humans. Moreover, glutamine has enterocyte-protective effects and modulates intestinal barrier function in stressed animals and humans as well as laboratory models (Amasheh et al., 2009; Hering and Schulzke, 2009). Although recent findings on glutamine concerned essentially ill humans (Wischmeyer, 2003; Fuchs and Bode, 2006; ...), few data were reported in very old female rats. For this reason, glutamine supplementation was used in such animals in order to study the benefit of glutamine on intestine metabolism in very old healthy animals.

In the current study, the hypothesis that glutamine is degraded by small intestine in glutamate and other carbon metabolites was tested by using ${ }^{13} \mathrm{C}$ nuclear magnetic resonance (NMR) to trace the metabolism of $\left[1-{ }^{13} \mathrm{C}\right]$ glutamine into enriched isotopomers of glutamine products degradation. As glutamate and $\mathrm{CO}_{2}$ were nevertheless major metabolites from glutamine, we used radiometry to follow $\mathrm{CO}_{2}$ production during 
incubation of proximal intestine. Before the experiment, adult (8-mo) and very old (27-mo) female Wistar rats were exposed to glutamine supplementation during $50 \%$ of their age, for 7 days in a row a month as previously described (Mignon et al. 2007a). These data demonstrated that glutamine pretreatment increased labeled glutamate production by isolated enterocytes, only in very old rats but decreased $\mathrm{CO}_{2}$ production in both adult and very old rats.

\section{MATERIALS AND METHODS}

\section{Materials}

L-Glutamine used in supplementation experiments was purchased from Jerafrance (Jeufosse, France). $\left[1-{ }^{13} \mathrm{C}\right]$ Glutamine was bought from Eurisotop, (Saint Aubin, France). $\left[{ }^{14} \mathrm{C}\right]$ Glutamate $(262 \mathrm{mCi} / \mathrm{mmol})$ and $\left[\mathrm{U}_{-}{ }^{14} \mathrm{C}\right]$ Glutamine $(255 \mathrm{mCi} / \mathrm{mmol})$ were purchased from Amersham (Bucks, UK).

\section{Animals}

These experiments were performed in accordance with current legislation on animal experimentation in France. Wistar rats originated from the experimental Unit of the Research Center of Theix. All animals were no pregnant. Rats were housed in the animal facilities until they reached the required age for the experiment. Animals were acclimatized in cages in groups of 5 in a room with a $12 \mathrm{~h}$ light/12 h dark cycle (lights on at 8.00 AM) at $22{ }^{\circ} \mathrm{C}$. The rats were fed rat pellets (AO3 "growth diet" until they attained 10 months, and AO4 "maintenance diet" from 10 to 27 months). These diets were purchased from Usine d'Alimentation Rationnelle, Villemoisson/Orge, France. Rats had free access water and were fed ad libitum. 


\section{Experimental design}

Adult (8-month aged) and old (27-month aged) female rats, weighing 350-400 g, were used in this experiment. Animals were exposed to preliminary treatment during $50 \%$ of their age i.e glutamine supplementation by the addition of glutamine to the drinking water for 7 days in a row a month (20\% of dietary protein). It consisted in an intermittent treatment of long duration in order not to deteriorate the renal function which can already be defective in the very old animals (Walrand et al., 2008). Control rats received only water during the same period. Animals were weighed before and after glutamine supplementation in order to demonstrate if glutamine supplementation was efficient to improve animal body weight. Adult and very old rats were studied about fifteen days after the last supplementation with glutamine. Rats were randomized to the following groups. Four groups of animals were used in this experiment: 1) control adults without supplementation ( $\mathrm{n}=10)$; 2) glutamine-supplemented adults $(\mathrm{n}=10) ; 3)$ control old rats without supplementation ( $\mathrm{n}=10) ; 4)$ glutamine-supplemented old rats $(\mathrm{n}=10)$.

\section{Isolation of jejunal epithelial cells and incubation}

Animals were anesthetized with pentobarbital sodium $(100 \mu \mathrm{l} / 100 \mathrm{~g}$ body wt, intraperitoneally). The abdominal cavity was opened and the small intestine extending from the pylorus to the caecum was removed. This tissue was emptied and rinsed with 150 $\mathrm{mM} \mathrm{NaCl}$ solution. A 2-cm length taken in proximal jejunum was cut and reserved for measurements of intestinal morphometry. The remnant small bowel was used for enterocytes isolation. Indeed, jejunal epithelial cells were prepared under continuous gas (oxygen/carbon dioxide, 19/1) and resuspended in bicarbonate Krebs-Henseleit buffer (pH7.4), as described previously (Vidal et al, 1988; Blachier et al, 1991; Lardy et al, 2004). The cell density of the final suspension was assessed by account of an aliquot in a 
Malassez hematocytometer. Cell viability was evaluated by the Trypan blue exclusion test and by the percentage of lactate deshydrogenase that was released in the extracellular medium at the onset of incubation (time 0 ) and after 30 min of incubation. At the end of incubation, $98 \%$ of cells were viable. For measurement of glutamine metabolites by ${ }^{13} \mathrm{C}$ NMR, about $300 \times 10^{6}$ cells were resuspended and incubated in $6 \mathrm{ml}$ of oxygenated KrebsHenseleit for $30 \mathrm{~min}\left(37^{\circ} \mathrm{C}\right)$ containing $\sim 17 \mathrm{mmol} / \mathrm{l}$ of $\left[1-{ }^{13} \mathrm{C}\right]$ glutamine. A supraphysiological level of glutamine was chosen to induce glutamine degradation and to be easily detected by NMR (Cremin et al., 1997). An aliquot fraction (25x106 cells) was taken and incubated, in parallel, in the presence of $1 \mathrm{nmol}$ of $\left[\mathrm{U}^{-14} \mathrm{C}\right]$ glutamine $\left(0.25 \mu\right.$ Curie) for the measurement of produced $\mathrm{CO}_{2}$. The incubation was stopped by addition of $30 \%$ perchloric acid to obtain cell suspension in an acidified incubation medium at $10 \%$ of perchloric acid.

\section{Perchloric extracts of enterocytes for NMR studies}

The acidified cell suspension was kept in ice for 10 min to precipitate proteins and then centrifuged for $10 \mathrm{~min}$ at $12000 \mathrm{~g}$ at $4^{\circ} \mathrm{C}$. The supernatant was decanted and neutralized with $\mathrm{KOH} 5 \mathrm{M}$. Then it was kept in ice for $10 \mathrm{~min}$ and centrifuged for $10 \mathrm{~min}$ at $12000 \mathrm{~g}$ at $4^{\circ} \mathrm{C}$ to rule out the $\mathrm{KClO} 4$ precipitate. The supernatant was removed and frozen at $-20^{\circ} \mathrm{C}$ until freeze-drying. The obtained sample was redissolved in $800 \mu \mathrm{l}$ of 99.9\% D2O containing 3mM EDTA and 20mM cycloleucine. Proceed by successive weightings because cycloleucine was used as both internal standard and quantification standard.

\section{${ }^{13} \mathrm{C}$ NMR spectroscopy}

The13C NMR experiments were performed at $100.625 \mathrm{MHz}$ using the DRX 400 Bruker spectrometer ( Ettlingen, Germany ) equipped with an heteronucleus probe. Spectra were acquired at $298 \mathrm{~K}$ with hard pulse of 5.5 us length to perform $90^{\circ}$. Each spectrum 
represented an average of 3500 scans with recycle time of 5.3 s. A sweep width of $23148 \mathrm{k}$ and $16 \mathrm{k}$ memory size were used. A WALTZ-16 composite pulse-decoupling sequence were applied just during the acquisition time to avoid the Nuclear Overhauser Effect. To analyse NMR data, the FIDs were processed with a 1-Hz line broadening before Fourier transformation. Chemical shifts are given relative to an internal cycloleucine standard set at 26 ppm.with a pH adjusted at 7.4, as reported by Badar-Goffer et al., 1990.

\section{Calculation of Glutamate production from $\left[1-{ }^{13} \mathrm{C}\right]$ Glutamine}

Glutamate produced was quantified by comparison with cycloleucine added in NMR tube to obtain a concentration of $20 \mathrm{mM}$.

$\left[{ }^{13} \mathrm{C} \mathrm{Glu}\right]=\underline{\text { Area Glu }} \underline{\underline{\mathrm{C} 2+\mathrm{C} 3+\mathrm{C} 4} 2 / 3) \times[\mathrm{RI}]}$

(Area RI /4)

where area $\mathrm{Glu}_{(\mathrm{C} 2+\mathrm{C} 3+\mathrm{C} 4}$ et area $\mathrm{RI}$ represented the sum of measured areas for the three carbons 2,3 and 4 of Glu ${ }^{13} \mathrm{C}$ and those of 4 carbons of cycloleucine used as internal reference; these areas were respectively divided by 3 and 4 to be reported to an individual carbon, [RI] was the concentration of cycloleucine in NMR tube in mM. $\left[{ }^{13} \mathrm{C} \mathrm{Glu}\right.$ ] was also expressed in $\mathrm{mM}$.

-The total amount of ${ }^{13} \mathrm{C}$ Glu produced in an assay by the total quantity of incubated enterocytes during $30 \mathrm{~min}$ in the présence of ${ }^{13} \mathrm{C}$ Gln was:

qGlu $=\frac{\left[{ }^{13} \mathrm{C} \mathrm{Glu}\right] \times \mathrm{V}}{1000}$

where $\mathrm{V}$ was the necessary volume to redissolve the freeze-dried sample in $\mu \mathrm{l}$. qGlu was expressed in $\mu$ mol.

•Production of Glu in nmol by million of enterocytes by incubation minute

Glu produit $=\underline{\text { qGlu }} \times \underline{1000}$

$\mathrm{N} \quad 30$

where $\mathrm{N}$ was the number of enterocytes millions in a given incubation, 30 was corresponding to $30 \mathrm{~min}$ of incubation and 1000 was the factor to convert $\mu \mathrm{mol}$ into nmol. 
Intestinal histomorphometry

2 cm-intestinal jejunal samples were opened, promptly attached on a small cork plate and fixed in $10 \%$ formalin then dehydrated and embedded in paraffin; $4 \mu$ sections were made and stained with hematoxylin-eosin-saffron. Histomorphometric analysis was performed to evaluate villous height and crypt depth in jejunum with image analysis morphometric SAMBA(TM) IPS32 Version 4.7 software. In case the wall of the villous and that of the crypt would thicken at the same time with Gln supplementation, we reported the difference between villous height and crypt depth and not the ratio villous height on crypt depth, as previously published (Mignon, Beaufrère, JPEN 2007a)

\section{Statistical analysis}

Values are given as means \pm SD. Variance analyses were performed to discriminate among the effects of aging (A), supplementation (S) and their interactions. Comparisons between 2 means were carried out using Student's $t$ test (unpaired test). The level of significance was at $\mathrm{p}<0.05$.

\section{RESULTS}

\section{Characteristics of animals}

Adult animals were young at the beginning of glutamine supplementation. For this reason, they grow during the treatment with or without glutamine supplementation $(\sim 15 \%)$. By contrast, glutamine supplementation has a beneficial effect on the body weight of very old rats; this treatment prevents the loss of weight due to the age (equivalent to $\sim 15 \%$ in animals without glutamine treatment) (fig 1). By contrast, glutamine supplementation did not stop sarcopenia (by example, tibialis mass was not improved by this supplementation: 1.245g in adults vs 1.003g in aged rats, regardless of treatment). 
Effect of long duration supplementation with glutamine on glutamate production from isolated and incubated enterocytes

A representative ${ }^{13} \mathrm{C}$ NMR spectrum of a glutamine-supplemented incubation in adult enterocytes was presented in fig 2. This spectrum was representative from both adult and very old enterocytes because detected peaks were similar whatever the age of animals. By contrast, peak integration of Glu (carbon C2, carbon C3, carbon C4) allowed to evidence differences in produced labeled Glu quantity. From these data, it was possible to calculate Glu production from $\left[1-{ }^{13} \mathrm{C}\right]$ Glutamine; these results were reported in the figure 3 . It should be pointed that only part (A) of the spectrum was used to quantify Glu because integration of $\mathrm{COOH}$ resonances may be disturbed by the huge peak of the remaining precursor, $\left[1-{ }^{13} \mathrm{C}\right]$ Glutamine. Long duration supplementation with glutamine before enterocytes preparation from adult and aged rats had no effect in adult enterocytes but significantly increased Glu production in very old enterocytes: a rise of $\sim 50 \%$ was observed. Indeed, the obtained value in NMR spectra increased from $0.43 \pm 0.13$ to $0.64 \pm 0.21 \mathrm{nmol} / 10^{6}$ viable cells/min.

Effect of long duration supplementation with glutamine on $\mathrm{CO}_{2}$ production from isolated and incubated enterocytes

$\mathrm{CO}_{2}$ production from adult and old incubated enterocytes in the presence of $\left[\mathrm{U}-{ }^{14} \mathrm{C}\right]$ Glutamine was presented in fig 3. $\mathrm{CO}_{2}$ production was higher in old than adult rats. However, $\mathrm{CO}_{2}$ production was always significantly smaller in glutamine-supplemented rats whatever their age. 
Effect of long duration supplementation with glutamine on intestine histomorphometry (Table 1).

By measuring the villus height and the crypt depth and calculating the difference, we failed les linéaments to demonstrate an effect of Gln supplementation on intestine, contrary to previous results obtained after Gln supplementation (Mignon, Beaufrère, JPEN 2007a).

\section{DISCUSSION}

To our knowledge, the current study is first to demonstrate that long duration supplementation with glutamine allowed us to differentiate glutamate and $\mathrm{CO}_{2}$ production from glutamine in isolated enterocytes in relation with age. This supplementation had, as previously reported Mignon et al, 2007, prevented the loss of body weight in very old rats without stopping sarcopenia.

A surprising point was that there was no change in both the value of villus height and this of crypt depth, nor even in the difference between villus height and crypt depth after long term treatment with glutamine. This was not in good agreement with results that we previously reported (Mignon, Beaufrère, 2007a). However, the difference between these two experiments was the time choice of Gln supplementation stop. In this experience, adult and very old rats were studied about fifteen days after the last supplementation with glutamine whereas previously, they were sacrificed just at the end of treatment. Because of Gln may be intensively used by gut to produce citrulline, as reported by Rutten et al. (2006) after Gln supplementation in catabolic state so that the supply of glutamine could be insufficient after 15 days of treatment disruption. Consequently, continuous supply of Gln may be necessary to compensate as better as possible these impaired metabolic pathways. 
Moreover, the Gln supply effect was not long-lasting so much Gln requirements must be intense with advanced age.

The findings of this study evidenced by ${ }^{13} \mathrm{C}$ NMR, the efficiency of long duration supplementation with glutamine to increase labeled glutamate production in very old rats. By contrast, the ratio $\mathrm{CO}_{2}$ /Glutamate became similar in adult and aged enterocytes at the end of incubation (0.606 \pm 0.165 in adults vs $0.507 \pm 0.279$ in aged rats) although this ratio was significantly different without glutamine supplementation $(0.803 \pm 0.381$ in adults vs $1.021 \pm 0.386$ in aged rats, $\mathrm{P}<0.01)$. Everything takes place as if $\mathrm{CO}_{2}$ production that is the main metabolic fate of glutamate within enterocytes and furnish energy to enterocytes (Blachier et al., 2009) became minor after glutamine supplementation whatever the age of animals. Because of glutamine supplementation maybe not improve protein synthesis rate in the jejunal mucosa (Ferreira S. Tannus et al., 2009), glutamate can be used by enterocytes to produce other amino acids L-aspartate, L-alanine, L-proline, L-ornithine and L-citrulline (as reported by Fleming et al., 1997) and glutathione, a crucial antioxidant in gastrointestinal. But these metabolites are not detectable by NMR in our experimental conditions.

In summary, our results suggest that, long-term treatment with glutamine started before advanced age: 1) it prevented the loss of rat body weight without limiting sarcopenia, 2) had a beneficial effect on enterocytes from very old rats by favoring the role of glutamate as precursor for glutathione, arginine, and proline biosynthesis, not detected in ${ }^{13} \mathrm{C}$ NMR spectra in our experimental conditions. Further investigations would be warranted to explore these metabolic pathways. 


\section{ACKNOWLEDGMENTS}

We would like to dedicate this manuscript to the memory of Dr Maurice Arnal. We would like to thank ... for critical review of the manuscript. We are also grateful... for its assistance in the secretariat and to Hélène Lafarge for contribution to the bibliography. 


\section{REFERENCES}

1. Amasheh M, Andres S, Amasheh S, et al. Barrier effects of nutritional factors. Ann N Y Acad Sci 2009;1165:267-73.

2. Badar-Goffer R, Bachelard HS, Morris PG. Cerebral metabolism of acetate and glucose studied by 13C-n m $\mathrm{r}$ spectroscopy A technique for investigating metabolic compartmentation in the brain. Biochem J 1990;266:133-9.

3. Bjerknes M, Cheng H. Gastrointestinal stem cells. II. Intestinal stem cells. Am J Physiol - Gastrointestin Liver Physiol 2005;289:G381-G387

4. Blachier F, Boutry C, Bos C, et al. Metabolism and Functions of L-Glutamate in the Epithelial Cells of the Small and Large Intestines. Am J Clin Nutr 2009;90:814S-21S.

5. Blachier F, Darcy Vrillon B, Sener A, et al. Arginine metabolism in rat enterocytes. Biochim Biophys Acta 1991;1092:304-10.

6. Boirie Y. Physiopathological mechanism of sarcopenia. Journal of Nutriton, Health \& Aging 2009;13:71723.

7. Cetinbas F, Yelken B, Gulbas Z. Role of glutamine administration on cellular immunity after total parenteral nutrition enriched with glutamine in patients with systemic inflammatory response syndrome. J Crit Care 2010;25:661.e1-6

8. Cremin JD, Fleming SE. Glycolysis is a source of pyruvate for transamination of glutamine amino nitrogen in jejunal epithelial cells. Am J Physiol - Gastrointestin Liver Physiol 1997;272:G575-G588

9. Curi R, Lagranha CJ, Doi SQ, et al. Glutamine-dependent changes in gene expression and protein activity. Cell Biochem Funct 2005;23:77-84.

10. Drozdowski L , Thomson AB. Aging and the intestine. World J Gastroenterol 2006;12:7578-84.

11. Dutta C, Hadley EC. The significance of sarcopenia in old age. J Gerontol A Biol Sci Med Sci 1995;50A:14.

12. Evans WJ. What is sarcopenia? J Gerontol A Biol Sci Med Sci 1995;50A:5-8.

13. Fleming SE, Zambell KL, Fitch MD. Glucose and glutamine provide similar proportions of energy to mucosal cells of rat small intestine. Am J Physiol - Gastrointestin Liver Physiol 1997;36:G968-G978

14. Fuchs BC, Bode BP. Stressing out over survival: glutamine as an apoptotic modulator. J Surg Res 2006;131:26-40.

15. Hering NA, Schulzke JD. Therapeutic options to modulate barrier defects in inflammatory bowel disease. Dig Dis 2009;27:450-4.

16. Hohn P, Gabbert H, Wagner R. Differentiation and aging of the rat intestinal mucosa. II. Morphological, enzyme histochemical and disc electrophoretic aspects of the aging of the small intestinal mucosa. Mech Ageing Dev 1978;7:217-26.

17. Kwon Y, Magnuson BA. Aging alters acute apoptotic response to azoxymethane in the colon of rats . Exp Gerontol 2007;42:1154-61.

18. Lardy H, Mouille B, Thomas M, et al. Enterocyte metabolism during early adaptation after extensive intestinal resection in a rat model. Surgery 2004;135:649-56. 
19. Mayer EA, Naliboff BD, Chang L, et al. Stress and the gastrointestinal tract - V. Stress and irritable bowel syndrome. Am J Physiol - Gastrointestin Liver Physiol 2001;280:G519-G524

20. Mignon M, Beaufrere AM, Combaret L, et al. Does long-term intermittent treatment with glutamine improve the well-being of fed and fasted very old rats? J Parenter Enter Nutr 2007;31:456-62.

21. Mondello S, Italiano D, Giacobbe MS, et al. Glutamine-supplemented total parenteral nutrition improves immunological status in anorectic patients. Nutrition 2010;26:677-81.

22. Munro HN. Adaptation of body protein metabolism in adult and aging man. Clin Nutr 1982;1:95-108.

23. Papet I, Dardevet D, Sornet C, et al. Acute phase protein levels and thymus, spleen and plasma protein synthesis rates differ in adult and old rats. J Nutr 2003;133:215-9.

24. Proctor DN, Balagopal P, Nair KS. Age-related sarcopenia in humans is associated with reduced synthetic rates of specific muscle proteins. J Nutr 1998;128:S351-S355

25. Reeds PJ, Burrin DG, Jahoor F, et al. Enteral glutamate is almost completely metabolized in first pass by the gastrointestinal tract of infant pigs. Am J Physiol - Endocrinol Metab 1996;270:E413-E418

26. Rutten EP, Engelen MP, Wouters EF, et al. Metabolic effects of glutamine and glutamate ingestion in healthy subjects and in persons with Chronic obstructive pulmonary disease. Am J Clin Nutr 2006; 83:11523.

27. Soderholm JD , Perdue MH. Stress and gastrointestinal tract. II. Stress and intestinal barrier function. Am J Physiol - Gastrointestin Liver Physiol 2001;280:G7-G13

28. Tannus AF, Darmaun D, Ribas DF, et al. Glutamine supplementation does not improve protein synthesis rate by the jejunal mucosa of the malnourished rat. Nutr Res 2009;29:596-601.

29. Thomas DR. Loss of skeletal muscle mass in aging: examining the relationship of starvation, sarcopenia and cachexia. Clin Nutr 2007;26:389-99.

30. Vicario M, Amat C, Rivero M, et al. Dietary glutamine affects mucosal functions in rats with mild DSSinduced colitis. J Nutr 2007;137:1931-7.

31. Vidal H, Comte B, Beylot $\mathrm{M}$, et al. Inhibition of glucose oxidation by vasoactive intestinal peptide in isolated rat enterocytes. J Biol Chem 1988;263:9206-11.

32. Volpi E, Nazemi R, Fujita S. Muscle tissue changes with aging. Curr Opin Clin Nutr Metab Care 2004;7:405-10.

33. Walrand S, Short KR, Bigelow ML, et al. Functional impact of high protein intake on healthy elderly people. Am J Physiol - Endocrinol Metab 2008;295:E921-E928

34. Wischmeyer PE. Clinical applications of L-glutamine: past, present, and future. Nutr Clin Pract 2003;18:377-85.

35. Yeh SL, Lai YN, Shang HF, et al. Effects of glutamine supplementation on innate immune response in rats with gut-derived sepsis. Br J Nutr 2004;91:423-9.

36. Yoshikawa TT. Aging and infectious diseases: state of the art. Gerontology 1984;30:275-8.

37. Young VR. Protein and amino acid metabolism with reference to aging and the elderly. In: Prinsley DM, Sandstead HH, eds. Alan R Liss, 1990:279-300. 


\section{FIGURE LEGENDS}

Figure 1. Effect of long term intermittent glutamine supplementation with treatment disruption before sacrifice on body weight of Wistar female rats. Initial body weight consisted in rat body weight before the treatment with Gln. Final body weight consisted in the body weight at the time of the sacrifice. ANOVA was performed to discriminate among effects of time (T) (beginning of supplementation or time of the sacrifice after supplementation), aging (A) and supplementation (S) and their interaction $(A * T, A * S$, $\left.T^{*} S, A * T * S\right)$. Significant effects of $A * S$ and $A * T * S$ were observed $(P<0.05) . * P<0.05$ vs '- initial adult rats, $\uparrow \mathrm{P}<0.05$ vs ‘- glutamine’ treated very old rats.

Figure 2. Proton-decoupled ${ }^{13} \mathrm{C}$ nuclear magnetic resonance (NMR) spectrum of a perchloric extract of incubated enterocytes from adult rats. Medium incubation contains $\sim 17 \mathrm{mM}$ of $\left[1-{ }^{13} \mathrm{C}\right]$ glutamine. Two regions are shown (A) 70 to 20 parts per million (ppm) and (B) 184 to $174 \mathrm{ppm}$ where ppm is chemical shift relative to tetramethylsilane. Abreviations Gln and Glu respectively mean glutamine and glutamate and number associated with abreviations refers to carbon position that ${ }^{13} \mathrm{C}$ atoms occupy within that compound. Peaks labeled cycloleucine consist in peak used for standardization of areas under peaks after integration. $\mathrm{X}$ and $\mathrm{Y}$ are unknown peaks.

Figure 3. Glutamate production from $\left[1-{ }^{13} \mathrm{C}\right]$ glutamine in incubated enterocytes from adult and very old rats treated or not with glutamine before sacrifice. Quantity of glutamate was calculated from the sum of areas of C2, C3 and C4. ANOVA was performed to 
discriminate among effects of aging (A) and supplementation (S) and their interaction $(A * S)$. Significant effects of $A * S$ was observed $(\mathrm{P}<0.05) * \mathrm{P}<0.05$ vs all other groups

Figure 4. $\mathrm{CO}_{2}$ production from $\left[\mathrm{U}-{ }^{14} \mathrm{C}\right]$ glutamine in incubated enterocytes from adult and very old rats treated or not with glutamine before sacrifice. ANOVA was performed to discriminate among effects of aging (A) and supplementation (S) and their interaction $(A * S)$. Significant effects of A and S were observed $(P<0.05)$. 


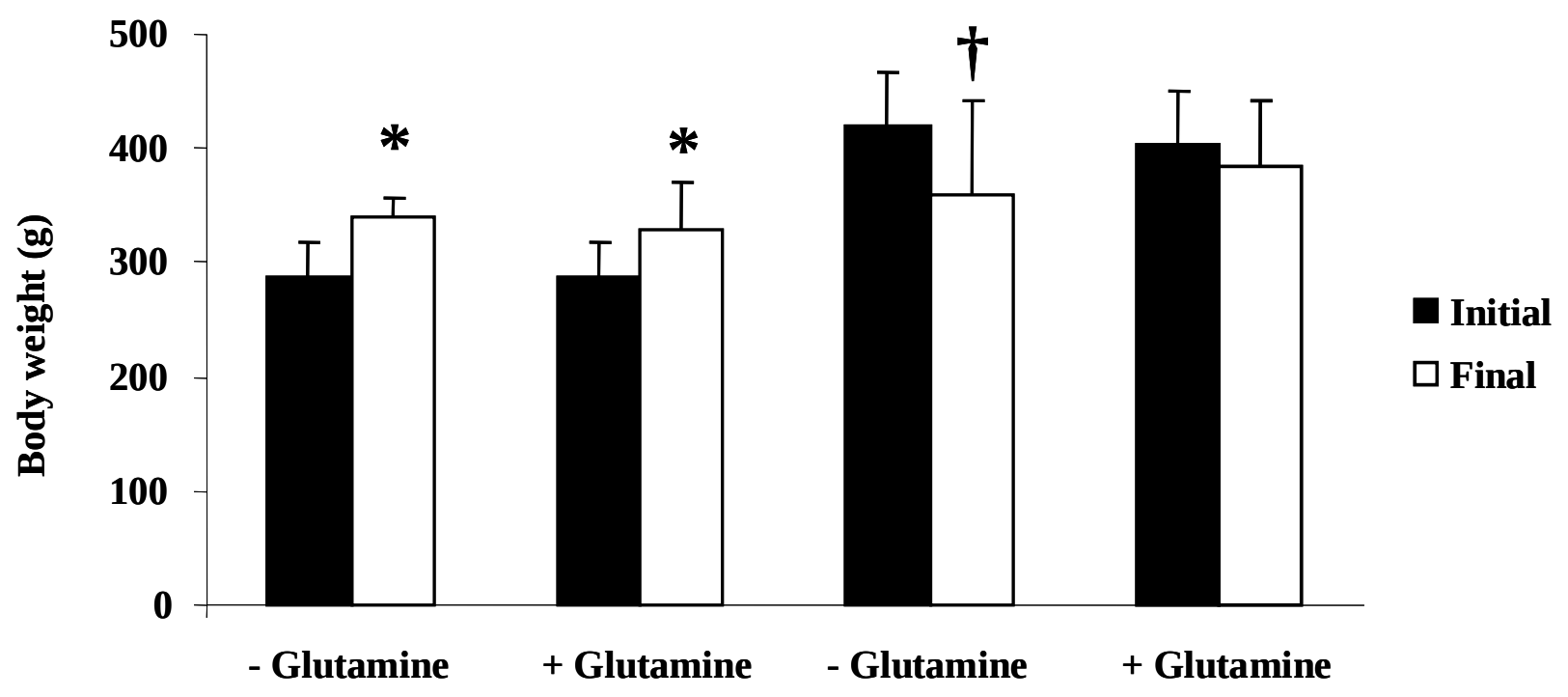

Adult rats

Old rats 


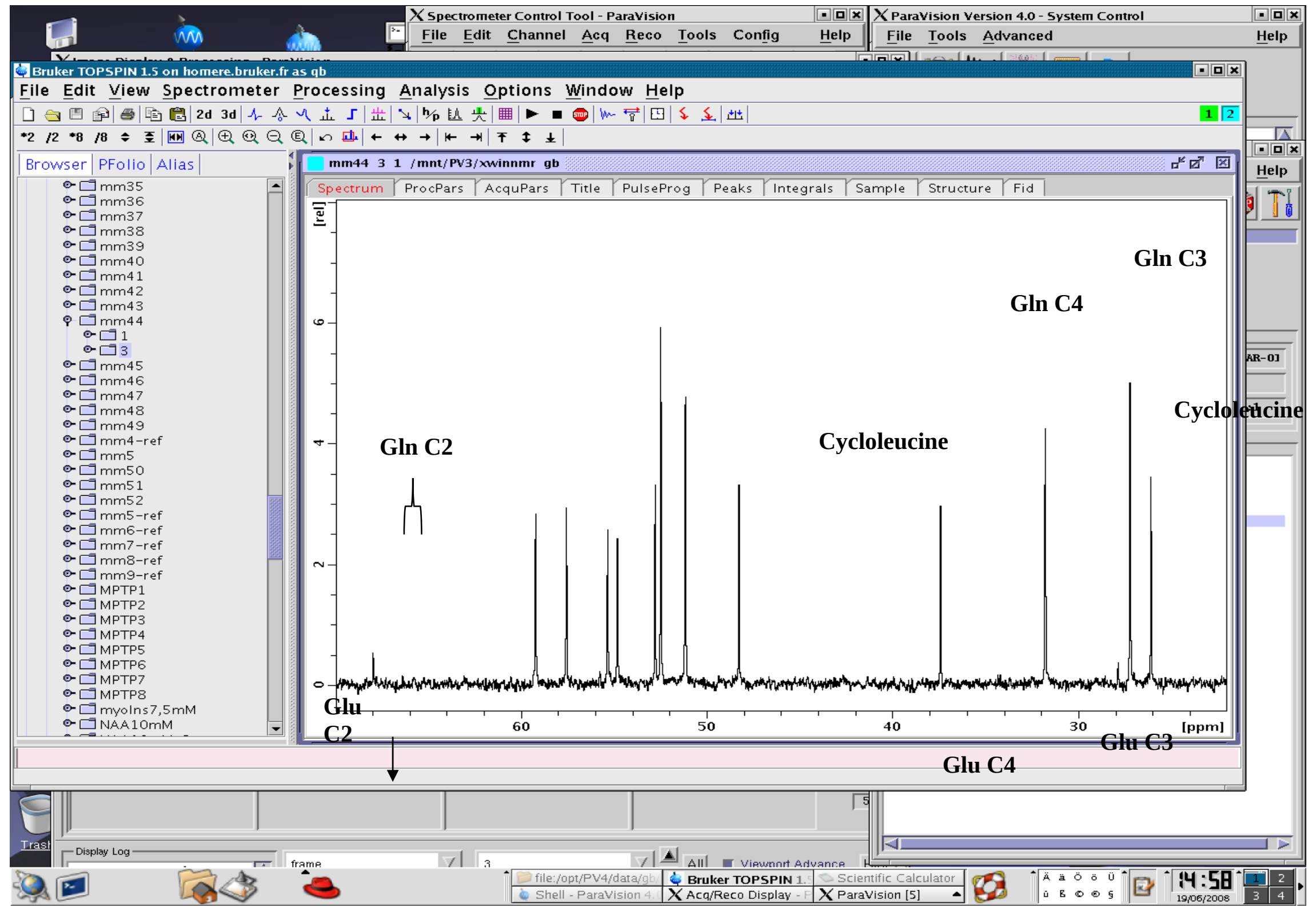


Glu production from [1-13C] Glutamine

(NMR signals C2 + C3 + C4)

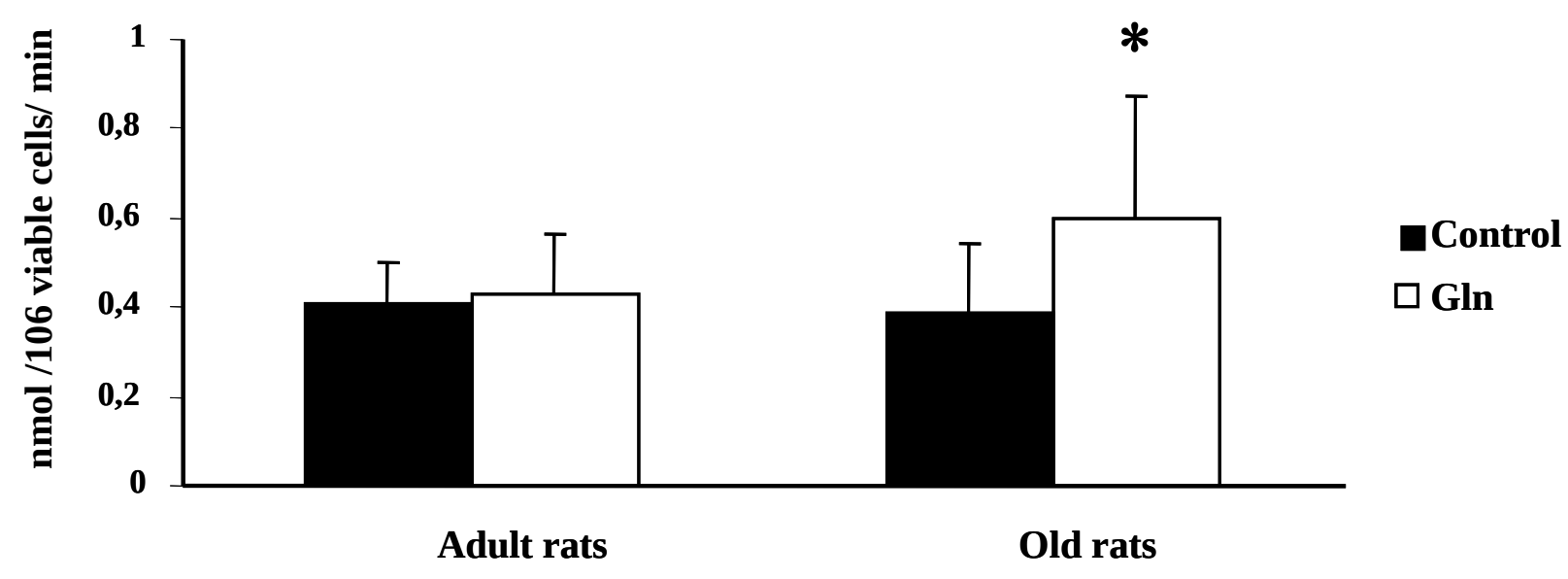

Effet age : non significatif

Effet traitement : significatif 


\section{$\mathrm{CO}_{2}$ production from $\left[\mathrm{U}-{ }^{14} \mathrm{C}\right]$ Glutamine}

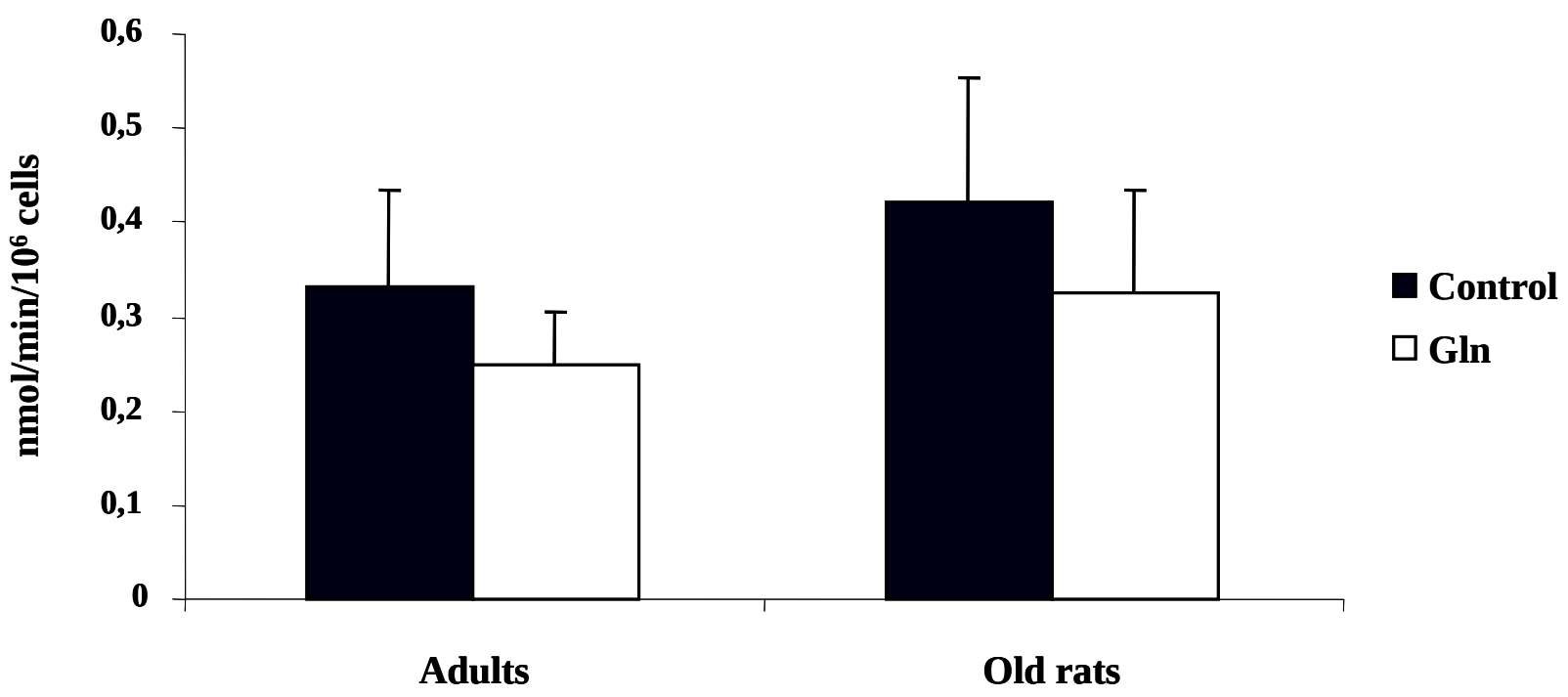

Effet age : significatif Effet traitement : significatif 
Table 1 Effect of long term intermittent glutamine supplementation with treatment disruption 15 days before sacrifice on intestine histomorphometry in female Wistar rats.

\begin{tabular}{lccc}
\hline & Villus height $(\mu \mathrm{m})$ & $\begin{array}{c}\text { Crypt depth } \\
(\mu \mathrm{m})\end{array}$ & $\begin{array}{c}\text { Villus height - Crypt depth } \\
(\mu \mathrm{m})\end{array}$ \\
\hline Adult rats & $506 \pm 77$ & $125 \pm 22$ & $380 \pm 61$ \\
$\quad$ Without glutamine & $546 \pm 88$ & $155 \pm 29$ & $390 \pm 64$ \\
$\quad$ With glutamine & $606 \pm 107$ & $163 \pm 50$ & $442 \pm 63$ \\
Very old rats & $558 \pm 90$ & $171 \pm 35$ & $387 \pm 67$ \\
$\quad$ Without glutamine & NS & A & NS \\
$\quad$ With glutamine & & & \\
\hline Significant effect of & ANOVA & &
\end{tabular}

Values are means $\pm \mathrm{SD}(\mathrm{n}=10)$. ANOVA was performed to discriminate among effects of aging $(\mathrm{A})$, supplementation $(\mathrm{S})$ and their interaction $\left(\mathrm{A}^{*} \mathrm{~S}\right)$. Significant effects of $\mathrm{A}$ was indicated $(\mathrm{P}<0.05)$. NS: not significant. 